Brazilian Journal

of Chemical

ISSN 0104-6632

Printed in Brazil

Engineering

www.scielo.br/bjce

Vol. 35, No. 03, pp. 943-956, July - September, 2018

dx.doi.org/10.1590/0104-6632.20180353s20170383

\title{
MODELING AND OPTIMIZATION OF REMOVAL OF CEFALEXIN FROM AQUATIC SOLUTIONS BY ENZYMATIC OXIDATION USING EXPERIMENTAL DESIGN
}

\author{
Reza Shokoohi ${ }^{1}$, Mohammad Taghi Samadi ${ }^{1}$, Mojtaba Amani ${ }^{2}$ and \\ Yousef Poureshgh ${ }^{1, *}$ \\ ${ }^{1}$ Department of Environmental Health Engineering, Faculty of Health and Research Center \\ for Health Sciences, Hamadan University of Medical Sciences, Hamadan, IR Iran \\ ${ }^{2}$ Ardabil University of Medical Sciences, Ardabil, IR Iran
}

(Submitted: July 19, 2017; Revised: September 14, 2017; Accepted: September 29, 2017)

\begin{abstract}
Antibiotics are used globally and, after use, they enter water sources in different ways. The presence of these compounds in the environment has created concerns about the toxicity of aquatic organisms and the emergence of antibiotic-resistant bacteria. The purpose of this study was to remove cefalexin from aqueous solutions by enzymatic oxidation using response surface methodology (RSM). For this purpose, batch experiments were performed to evaluate the effect of independent variables, including temperature, $\mathrm{pH}$, contact time, enzyme activity, HBT mediator concentration, and antibiotic concentration. The residual cefalexin concentration was determined by HPLC. The Box-Behnken design of experiments and RSM were used to evaluate the overlap between variables. The results showed that the oxidation efficiency increased with increasing contact time and enzyme activity and decreasing antibiotic concentration. The highest and lowest removal percentages were $90.5 \%$ and $5.54 \%$, respectively. Considering the value of $\mathrm{R}^{2}(0.946)$ and adjusted $\mathrm{R}^{2}(0.95)$ in the RSM model, one can state that the selected model is suitable for data analysis. Finally, the second-order polynomial analysis and the quadratic model were used as the best model for finding the relationship between the main variables and cefalexin removal efficiency. The Box-Behnken Design model can be effective for optimizing enzymatic oxidation of cefalexin, and laccase can be used to remove cefalexin.
\end{abstract}

Keywords: Enzymatic oxidation, laccase, cefalexin, Box-Behnken design.

\section{INTRODUCTION}

Medications are spreading into the environment and nature in many ways, including wastewater, and urban, medical, and industrial waste (Nazari et al., 2016).
Currently, a wide variety of pharmaceutical products is very common in urban and factories wastewater (Azizi etal., 2017; Khetan and Collins, 2007; Martinez, 2009). The formation of antibiotic compounds in aquatic environments is an emerging subject, whose

*Corresponding author: Yousef Poureshgh, E-mail: yusef.poureshg@gmail.com. 
source is mainly the pharmaceutical industry, as well as the use of veterinary and human medicines (Fuoco, 2012; Le-Minh et al., 2010). About 30-90\% of the dose consumed of these compounds and used by humans or animals can remain intact without degradation in their body, and is largely excreted as an active compound (Chee-Sanford et al., 2001; Jung, 2003). Many of these antibiotics have a toxic nature for smaller organisms in the environment, which can have a long-term indirect effect on environmental sustainability (Baquero et al., 2008; Martinez, 2009; Young et al., 2013). These compounds are highly resistant to biodegradation processes and remain in the environment for a long time due to their high stability. Their continued presence in the environment has caused many concerns for their long-term effects on human health (Fazlzadeh et al., 2016; Nazari et al., 2016).

Among the drugs, antibiotic isolation from sewage is of great importance due to its high utilization. Cefalexin (CEX) is one of the most used cephalosporin antibiotics, whose use and annual sales revenue in the early 21 st century were 3,000 and $850,000,000$ dollars respectively (Barber et al., 2004; Leili et al., 2018). Table 1 shows the main features of CEX (Estrada et al., 2012).

CEX is one of the antibiotics that is prescribed a lot and produced in large quantities (Elmolla and Chaudhuri, 2010; Sirés and Brillas, 2012). This antibiotic is widely used to treat a variety of human infections caused by Gram-positive and Gram-negative bacteria. Several serious environmental hazards from CEX in the environment have been a public health problem for many years (Ahmed and Theydan, 2012; Fazlzadeh et al., 2016; Vilt and Ho, 2009).

Removal of antibiotics from the environment involves high costs because the pharmaceutical industries should properly clean their wastewater before discharging into the environment. Therefore, the elimination of antibiotic residues from the environment is of particular importance and is an attractive subject for a case study (Kim et al., 2005; Košutić et al., 2007; Watkinson et al., 2007).

Typical routine separation methods of CEX from aqueous solution are liquid membrane separation, solid phase extraction, biological inoculation, electrophoton oxidation, Nano-filtration and Sono-chemical degradation (Estrada et al., 2012; Guo et al., 2010; Vilt and Ho, 2011; Zazouli et al., 2010).

The enzymatic oxidation of resistant pollutants is an environmentally friendly alternative method compared to conventional physicochemical methods (Hai et al., 2013). Over the past three decades, the use of biodegradation by enzyme has received a great deal of attention as an environmentally sustainable solution. The enzymatic oxidation method is an alternative to old methods because it can be efficient at different concentrations of contaminants. This method is easily controllable, requires low energy, and has the least impact on the ecosystem (Duran and Esposito, 2000; Karam and Nicell, 1997). Laccase is a multi-copper oxidase that is effective in the biodegradation process. Laccase performs selective oxidation catalysis of several natural and non-natural substrates using the air as a green oxidant. The only by product of this process is $\mathrm{H}_{2} \mathrm{O}$ (Forootanfar et al., 2012). This enzyme is widely used in paper and paper pulp (Widsten and Kandelbauer, 2008), biological sensors (Madhavi and Lele, 2009), organic synthesis (Heidary et al., 2014), and especially in the removal of anti-inflammatory drug wastes (NSAIMs) (Lloret et al., 2013), benzodiazepines (OstadhadiDehkordi et al., 2012), diclofenac (Xu et al., 2015) and carbamazepine (Hata et al., 2010).

One of the statistical models used in designing the experiments is the RSM method, which is a simple, effective way to optimize various processes. This method can be done using the central composite design (CCD) or Box-Behnken Design (BBD).

According to our best knowledge, there are no investigations about the removal of cephalexin (CEX) from aqueous solutions by the laccase enzyme until now. The current study is focused on the ability of laccase enzyme to remove cephalexin from aqueous solution. Moreover, the conversion of cephalexin catalyzed by laccase was optimized using the Box Behnken design of experiments, taking into account the major variables (6 variables) involved in enzymatic oxidation. In most studies, this has been done with a maximum of three to four parameters.

Table 1. Cefalexin properties

\begin{tabular}{ccc}
\hline Solubility & Molecular Weight & Structure \\
\hline & & \\
\hline
\end{tabular}




\section{METHODS}

\section{Study method}

This study is an experimental-practical study carried out on a laboratory scale. The study of CEX removal as a dependent variable against independent parameters such as initial antibiotic concentration, temperature, $\mathrm{pH}$, residence time, HBT mediator concentration and enzyme activity was performed and optimization of the process and the interaction of variables were investigated using BBD.

\section{Required chemicals}

The enzyme used was laccase extracted from Trametes versicolor (EC1.10.3.2), CEX, hydroxybenzotriazole (HBT) and 2,2'-azino-bis (3-ethylbenzothiazoline-6sulphonic acid) (ABTS) mediators were from SigmaAldrich USA. Sodium citrate and citric acid with a purity of $99.5 \%$ and methanol (HPLC grade) were from Merck Germany. Distilled water prepared using a membrane method was used to prepare all solutions and buffers.

Sodium citrate and citric acid were used to prepare a citrate buffer with a specific $\mathrm{pH}$, so that $0.1 \mathrm{~mL}$ citrate buffer was used with the $\mathrm{pH}$ required for the preparation of all solutions. To ensure the $\mathrm{pH}$ of the solution, the HACK pH meter was used.

To measure the enzyme activity, a Shimadzu UV180 spectrophotometer was used. To measure CEX concentration, HPLC-UV (column C18 of internal diameter $4.6 \mathrm{~mm}$ and $250 \mathrm{~mm}$ long) and methanolcarrier phase (30 to $70 \%$ ), and a detection wavelength of $263 \mathrm{~nm}$ were used. The devices used were calibrated and their calibration curves were plotted.

\section{Determining the activity of the enzyme}

ABTS was used as substrates to measure the activity of laccase enzyme. First, a $2 \mathrm{mM}$ solution was prepared of ABTS in citrate buffer $(0.1 \mathrm{~m}, \mathrm{pH}=4.5)$. After the reaction time, the absorbance of the reaction solution at $420 \mathrm{~nm}$ was measured using a spectrophotometer. Based on the molar coefficient, ABTS $\left(\varepsilon_{420}=36000\right.$ $\mathrm{M}^{-1} \mathrm{~cm}^{-1}$ ) was converted to enzyme units. The amount of enzyme that can oxidize in 1 minute 1 micromole of the substrate at $\mathrm{pH}=4.5$ and at $25^{\circ} \mathrm{C}$ is equal to one laccase enzyme activity unit (Donati et al., 2015).

\section{Optimization of enzymatic oxidation using the RSM method}

The oxidation parameters include temperature, $\mathrm{pH}$, time, enzyme activity, HBT concentration and CEX concentration. In this method, the 6 parameters intended were examined at three levels: high $(+1)$, medium $(0)$ and low (-1). Table 2 shows the factors and levels. Taking into account 6 variables, and using the Box-Behnken design of experiments (BBD), the number of experiments required for statistical analysis was determined to be 54 experiments with two replicates of each experiment; the number of experiments in this study was thus 108 experiments. Determining the appropriate range for the parameters studied was done by performing several oxidation experiments at the upper and lower levels of the parameter, as well as previous studies in this field. Experimental conditions and the results of enzymatic oxidation in cefalexin removal are shown in Table 2.

In this method, the experiments were performed according to the limits of BBD. For performing each experiment, $10 \mathrm{~mL}$ of a solution containing a specific concentration of CEX antibiotic was contacted at a specified temperature and $\mathrm{pH}$ over a specified period with a certain amount of enzyme and mediator. Samples were sampled at a volume of $0.5 \mathrm{cc}$ after reactions and were filtered with a 0.22 -micron filter. The antibiotic residue in the solution was measured by HPLC and the percentage of CEX removal calculated by Eq. (1):

$$
R \%=\left(\left(C_{0}-C_{t}\right) / C_{0}\right) \times 100
$$

in which $\mathrm{C}_{t}$ and $\mathrm{C}_{0}$ are the initial and final concentrations in ppm, respectively.

Table 2. Levels and selected codes of variables for designing the Box-Behnken Test

\begin{tabular}{|c|c|c|c|c|c|}
\hline \multirow{2}{*}{ Variable } & \multirow{2}{*}{ Unit } & \multirow{2}{*}{ Factors } & \multicolumn{3}{|c|}{ Range and level } \\
\hline & & & Low $(-1)$ & Middle (0) & High $(+1)$ \\
\hline pH & - & A & 3 & 5 & 7 \\
\hline Temperature & ${ }^{\circ} \mathrm{C}$ & $\mathrm{B}$ & 30 & 45 & 60 \\
\hline Time & $\min$ & $\mathrm{C}$ & 15 & 37.5 & 60 \\
\hline Activity & $\mathrm{U} / \mathrm{mL}$ & $\mathrm{D}$ & 0.25 & 1 & 1.75 \\
\hline Mediator concentration & $\mathrm{mM}$ & $\mathrm{E}$ & 0.5 & 1 & 1.5 \\
\hline Concentration of cefalexin & $\mathrm{mg} / \mathrm{L}$ & $\mathrm{F}$ & 10 & 80 & 100 \\
\hline
\end{tabular}


The results of the research were analyzed using Design Expert 7 software. The experiments were randomized to minimize system error. The interacting interference model coefficients are interpretations of the level of cefalexin removal (response) as the independent variable function. Data were analyzed by multivariate regression and the coefficients were analyzed by ANOVA with respect to the significance level $(\mathrm{P} \leq 0.05)$. 3D graphs (response surface curves) were plotted to examine the relationship between responses and independent variables.

\section{RESULTS AND DISCUSSION}

\section{Verifying the model}

Experiments were performed under the conditions specified by the BBD model in a standard manner. The results of the statistical plan and response procedures are summarized in Table 3 . The results showed that the efficacy of CEX removal in different values of the six main variables was very different, which is the result of the effect of different levels of variables on the efficacy of CEX oxidation. According to the results of the study and Table 3, the highest and lowest percentages of CEX removal by the BBD method, respectively, were obtained in test experiments 15 and 26, which were about $90.5 \%$ and $5.54 \%$ respectively.

In addition, a small difference between the actual and predicted efficiency indicates the high accuracy of the model in estimating the response variable (CEX removal efficiency). Accordingly, second-order polynomial analysis and a quadratic model were used to find the relationship between the main variables and CEX oxidation efficiency as the best model. To validate the model and variance analysis, ANOVA was used, whose results are shown in Table 4. Accordingly, the efficacy of cefalexin removal for the significant variables is obtained according to the following Eq. (2):

$$
\begin{aligned}
R= & -511.6+8.8 * A+93.858 * B+2.4 * C+ \\
& 52.5 * D+144.93 * E-0.013 * F-0.086 * A^{2}- \\
& 9.16 * B^{2}-2.38 * B * D-2.51 * B * E- \\
& 0.0448 * B * F-0.021 * C^{2}-13.19 * D^{2}- \\
& 54.91 * E^{2}-0.00324 * F^{2}
\end{aligned}
$$

wher: $\mathrm{A}$ is the reaction temperature, $\mathrm{B}$ is $\mathrm{pH}$, a term with no metric, $\mathrm{C}$ is the reaction duration ( $\mathrm{min}$ ), $\mathrm{D}$ is the enzyme activity $(\mathrm{U} / \mathrm{mL}), \mathrm{E}$ is the HBT mediator concentration $(\mathrm{mM})$ and $\mathrm{F}$ is the cefalexin concentration $(\mathrm{mg} / \mathrm{L})$.
The parameter F-value is the standard deviation of the data from the mean value. In general, for a model that predicts test results successfully, an F-value is very high and a p-value less than 0.05 means that the model is significant. For this model, the values of F-value and p-value were 78.88 and $\mathrm{P}<0.0001$, respectively, indicating that the model was completely significant. In this equation, the linear parameters were $\mathrm{E}, \mathrm{D}, \mathrm{C}, \mathrm{B}, \mathrm{A}$ and $\mathrm{F}$; second order parameters of the model were $\mathrm{D}^{2}, \mathrm{C}^{2}, \mathrm{~B}^{2}, \mathrm{~A}^{2}$, $\mathrm{E}^{2}$ and $\mathrm{F}^{2}$, along with the interaction parameters $\mathrm{BD}, \mathrm{BE}$ and $\mathrm{BF}$. As the values of $\mathrm{R}^{2}$ and $\mathrm{R}^{2}$ adj are close to 1 , it indicates a better relationship between laboratory and calculated results. In this model, the value of the parameter $\mathrm{R}^{2}(0.946)$ is in accordance with $\mathrm{R}^{2}$ adj (0.95) that shows the model accuracy. The signal-to-noise ratio is measured using the Adequate Precision function, where a ratio more than 4 is desirable. For this model, the Adequate Precision was $30.5 \%$, which indicates a high signalto-noise ratio (Mourabet et al., 2012). The DurbinWatson test was used to check the independence of the errors (the difference between the actual values and the values predicted by the regression equation) and the Durbin-Watson test statistic was 1.74. As it is 1.5 to 2.5 , the assumption of the absence of correlation between the errors is not rejected and regression can be used.

In the analysis of experiments and the use of linear models, the validity of a model depends on some assumptions, including residuals that should have a normal distribution with mean zero, constant variance $\left(\partial^{2}\right)$, and residuals independent of each other. Fig. 1 shows these assumptions. Fig. 1 (a) shows the examination of residuals being normal, and given that no deviations were seen in the normality of the residuals, the assumption of the normality of the residuals was confirmed. Fig. 1 (b) is used to check the assumption of constancy of the variances of the residuals. If there is no particular trend in this graph, the assumption that the variance is constant is accepted. Given that in this diagram there is no particular trend indicating the increase or decrease of variance, the assumption of constant variance is accepted. Diagram 1c shows the independence between the residuals. If a trend like a sinusoid is not visible in this chart, then the assumption in question is accepted as well. In this chart, no particular trend shows, ruling out the independence of the residuals. Fig.1 (d) shows that the proposed model for CEX removal is well suited to the experimental data. 
Table 3. Design and test results

\begin{tabular}{|c|c|c|c|c|c|c|c|}
\hline \multirow{2}{*}{ Run } & A & $\mathrm{B}$ & $\mathrm{C}$ & $\mathrm{D}$ & $\mathrm{E}$ & $\mathrm{F}$ & \multirow{2}{*}{$\mathrm{R}(\%)$} \\
\hline & $\mathrm{T}\left({ }^{\circ} \mathrm{C}\right)$ & $\mathrm{pH}$ & Time(min) & $\mathrm{En}(\mathrm{U} / \mathrm{mL})$ & $\mathrm{HBT}(\mathrm{mM})$ & $\mathrm{C}(\mathrm{mg} / \mathrm{l})$ & \\
\hline 1 & 45 & 5 & 15 & 0.25 & 1 & 10 & 37.1 \\
\hline 2 & 45 & 5 & 60 & 0.25 & 1 & 100 & 39.2 \\
\hline 3 & 45 & 7 & 37.5 & 1 & 0.5 & 10 & 16.35 \\
\hline 4 & 30 & 5 & 60 & 1 & 1 & 10 & 64.6 \\
\hline 5 & 45 & 7 & 37.5 & 1 & 1.5 & 10 & 25.1 \\
\hline 6 & 45 & 5 & 15 & 0.25 & 1 & 100 & 17.4 \\
\hline 7 & 30 & 3 & 37.5 & 0.25 & 1 & 55 & 7.6 \\
\hline 8 & 60 & 3 & 37.5 & 0.25 & 1 & 55 & 14.5 \\
\hline 9 & 45 & 3 & 37.5 & 1 & 0.5 & 10 & 33 \\
\hline 10 & 60 & 7 & 37.5 & 0.25 & 1 & 55 & 7.32 \\
\hline 11 & 45 & 3 & 15 & 1 & 0.5 & 55 & 8.9 \\
\hline 12 & 45 & 7 & 60 & 1 & 0.5 & 55 & 18 \\
\hline 13 & 30 & 5 & 37.5 & 0.25 & 1.5 & 55 & 29.76 \\
\hline 14 & 45 & 3 & 60 & 1 & 1.5 & 55 & 37.5 \\
\hline 15 & 45 & 3 & 37.5 & 1 & 0.5 & 100 & 5.54 \\
\hline 16 & 60 & 3 & 37.5 & 1.75 & 1 & 55 & 31.4 \\
\hline 17 & 30 & 5 & 37.5 & 1.75 & 0.5 & 55 & 24.6 \\
\hline 18 & 45 & 3 & 60 & 1 & 0.5 & 55 & 20.6 \\
\hline 19 & 45 & 5 & 37.5 & 1 & 1 & 55 & 77.1 \\
\hline 20 & 45 & 5 & 15 & 1.75 & 1 & 10 & 75.5 \\
\hline 21 & 45 & 5 & 37.5 & 1 & 1 & 55 & 79 \\
\hline 22 & 45 & 7 & 15 & 1 & 1.5 & 55 & 8.5 \\
\hline 23 & 60 & 5 & 37.5 & 1.75 & 0.5 & 55 & 54.7 \\
\hline 24 & 30 & 5 & 15 & 1 & 1 & 100 & 15.95 \\
\hline 25 & 60 & 5 & 15 & 1 & 1 & 100 & 17.3 \\
\hline 26 & 45 & 5 & 60 & 1.75 & 1 & 10 & 90.5 \\
\hline 27 & 30 & 5 & 37.5 & 1.75 & 1.5 & 55 & 51 \\
\hline 28 & 45 & 7 & 37.5 & 1 & 0.5 & 100 & 7.3 \\
\hline 29 & 45 & 3 & 15 & 1 & 1.5 & 55 & 16 \\
\hline 30 & 45 & 7 & 60 & 1 & 1.5 & 55 & 20.8 \\
\hline 31 & 30 & 5 & 60 & 1 & 1 & 100 & 47.33 \\
\hline 32 & 45 & 7 & 15 & 1 & 0.5 & 55 & 7.65 \\
\hline 33 & 60 & 5 & 15 & 1 & 1 & 10 & 47 \\
\hline 34 & 45 & 5 & 15 & 1.75 & 1 & 100 & 31 \\
\hline 35 & 60 & 7 & 37.5 & 1.75 & 1 & 55 & 13.1 \\
\hline 36 & 45 & 7 & 37.5 & 1 & 1.5 & 100 & 13.6 \\
\hline 37 & 45 & 5 & 37.5 & 1 & 1 & 55 & 78.5 \\
\hline 38 & 45 & 3 & 37.5 & 1 & 1.5 & 100 & 22.8 \\
\hline 39 & 30 & 7 & 37.5 & 1.75 & 1 & 55 & 10 \\
\hline 40 & 60 & 5 & 37.5 & 0.25 & 0.5 & 55 & 27.6 \\
\hline 41 & 45 & 5 & 37.5 & 1 & 1 & 55 & 78.3 \\
\hline 42 & 30 & 3 & 37.5 & 1.75 & 1 & 55 & 28.3 \\
\hline 43 & 60 & 5 & 60 & 1 & 1 & 100 & 49.4 \\
\hline 44 & 45 & 5 & 60 & 1.75 & 1 & 100 & 66 \\
\hline 45 & 45 & 5 & 37.5 & 1 & 1 & 55 & 78.85 \\
\hline 46 & 30 & 5 & 15 & 1 & 1 & 10 & 30.5 \\
\hline 47 & 60 & 5 & 37.5 & 1.75 & 1.5 & 55 & 58 \\
\hline 48 & 60 & 5 & 60 & 1 & 1 & 10 & 63 \\
\hline 49 & 45 & 5 & 60 & 0.25 & 1 & 10 & 73.6 \\
\hline 50 & 30 & 7 & 37.5 & 0.25 & 1 & 55 & 6.45 \\
\hline 51 & 60 & 5 & 37.5 & 0.25 & 1.5 & 55 & 43.6 \\
\hline 52 & 45 & 3 & 37.5 & 1 & 1.5 & 10 & 49 \\
\hline 53 & 45 & 5 & 37.5 & 1 & 1 & 55 & 77.45 \\
\hline 54 & 30 & 5 & 37.5 & 0.25 & 0.5 & 55 & 15.06 \\
\hline
\end{tabular}


Table 4. ANOVA results for CEX removal

\begin{tabular}{|c|c|c|c|c|c|c|}
\hline & Sum of & & Mean & F-value & p-value & \\
\hline Source & Squares & df & Square & & Prob $>$ F & \\
\hline Model & 63384.21 & 27 & 2347.56 & 78.98 & $<0.0001$ & significant \\
\hline A & 751.29 & 1 & 751.29 & 25.28 & $<0.0001$ & significant \\
\hline B & 1290.22 & 1 & 1290.22 & 43.41 & $<0.0001$ & significant \\
\hline $\mathrm{C}$ & 6452.43 & 1 & 6452.43 & 217.09 & $<0.0001$ & significant \\
\hline D & 3857.10 & 1 & 3857.10 & 129.77 & $<0.0001$ & significant \\
\hline $\mathrm{E}$ & 1447.57 & 1 & 1447.57 & 48.70 & $<0.0001$ & significant \\
\hline $\mathrm{F}$ & 5983.55 & 1 & 5983.55 & 201.31 & $<0.0001$ & significant \\
\hline $\mathrm{AB}$ & 11.61 & 1 & 11.61 & 0.39 & 0.5338 & \\
\hline $\mathrm{AC}$ & 79.34 & 1 & 79.34 & 2.67 & 0.1063 & \\
\hline $\mathrm{AD}$ & 12.54 & 1 & 12.54 & 0.42 & 0.5179 & \\
\hline $\mathrm{AE}$ & 113.00 & 1 & 113.00 & 3.80 & 0.0547 & \\
\hline $\mathrm{AF}$ & 33.15 & 1 & 33.15 & 1.12 & 0.2942 & \\
\hline $\mathrm{BC}$ & 10.50 & 1 & 10.50 & 0.35 & 0.5541 & \\
\hline $\mathrm{BD}$ & 202.85 & 1 & 202.85 & 6.82 & 0.0108 & significant \\
\hline $\mathrm{BE}$ & 228.29 & 1 & 228.29 & 7.68 & 0.0070 & significant \\
\hline $\mathrm{BF}$ & 260.02 & 1 & 260.02 & 8.75 & 0.0041 & significant \\
\hline $\mathrm{CD}$ & 15.11 & 1 & 15.11 & 0.51 & 0.4779 & \\
\hline $\mathrm{CE}$ & 59.06 & 1 & 59.06 & 1.99 & 0.1626 & \\
\hline $\mathrm{CF}$ & 49.95 & 1 & 49.95 & 1.68 & 0.1986 & \\
\hline $\mathrm{DE}$ & $2.025 \mathrm{E}-03$ & 1 & $2.025 \mathrm{E}-03$ & $6.813 \mathrm{E}-05$ & 0.9934 & \\
\hline $\mathrm{DF}$ & 38.91 & 1 & 38.91 & 1.31 & 0.2560 & \\
\hline $\mathrm{EF}$ & 0.36 & 1 & 0.36 & 0.012 & 0.9126 & \\
\hline $\mathrm{A}^{2}$ & 7621.83 & 1 & 7621.83 & 256.43 & $<0.0001$ & significant \\
\hline $\mathrm{B}^{2}$ & 27602.78 & 1 & 27602.78 & 928.67 & $<0.0001$ & significant \\
\hline $\mathrm{C}^{2}$ & 2395.80 & 1 & 2395.80 & 80.60 & $<0.0001$ & significant \\
\hline $\mathrm{D}^{2}$ & 1114.87 & 1 & 1114.87 & 37.51 & $<0.0001$ & significant \\
\hline$E^{2}$ & 3915.03 & 1 & 3915.03 & 131.72 & $<0.0001$ & significant \\
\hline $\mathrm{F}^{2}$ & 816.24 & 1 & 816.24 & 27.46 & $<0.0001$ & significant \\
\hline Residual & 2348.10 & 79 & 29.72 & & & \\
\hline Cor Total & 65732.31 & 106 & & & & \\
\hline
\end{tabular}

The effect of independent variables on CEX removal is shown in Fig. 2 The percentage of removal of CEX at $\mathrm{pH} 5$, temperature $45^{\circ} \mathrm{C}$, and HBT mediator concentration was $1 \mathrm{mM}$, and with increasing and decreasing $\mathrm{pH}$, temperature and HBT from these values, efficiency decreased. By increasing the concentration of CEX from 10 to $100 \mathrm{mg} / \mathrm{L}$, the removal rate was reduced. Moreover, the deletion percentage increased with increasing contact time from 15 to 60 minutes and enzyme activity from 0.25 to $1.75 \mathrm{U} / \mathrm{mL}$. In this research, all of the variables considered have an optimal point in the selected domain, suggesting that the domains are properly selected.

In this study, the effect of effective factors on the oxidation process was investigated by a Pareto chart. As shown in Fig. 3, pH and temperature are the most important parameters for CEX oxidation.
The importance of time, the concentration of CEC, HBT concentration and enzyme activity were in the following ranks. It is also observed that time, enzyme activity and HBT concentration have a positive effect and $\mathrm{pH}$, temperature and $\mathrm{CEX}$ concentration have a negative effect on CEX oxidation.

\section{The effect of temperature}

One of the most important and influential factors in biotechnology is temperature. Enzymes show a specific sensitivity to temperature variations. The heat deforms the enzyme's 3D structure, destroying the active enzymes and disabling them. Enzyme activity reduces or deactivates at temperatures below $10{ }^{\circ} \mathrm{C}$ and above $60{ }^{\circ} \mathrm{C}$ (Fabbrini et al., 2002; Liu, 2006). In the study of Asgher et al. (2017), the highest activity of free laccase enzyme was observed at $45^{\circ} \mathrm{C}$. 

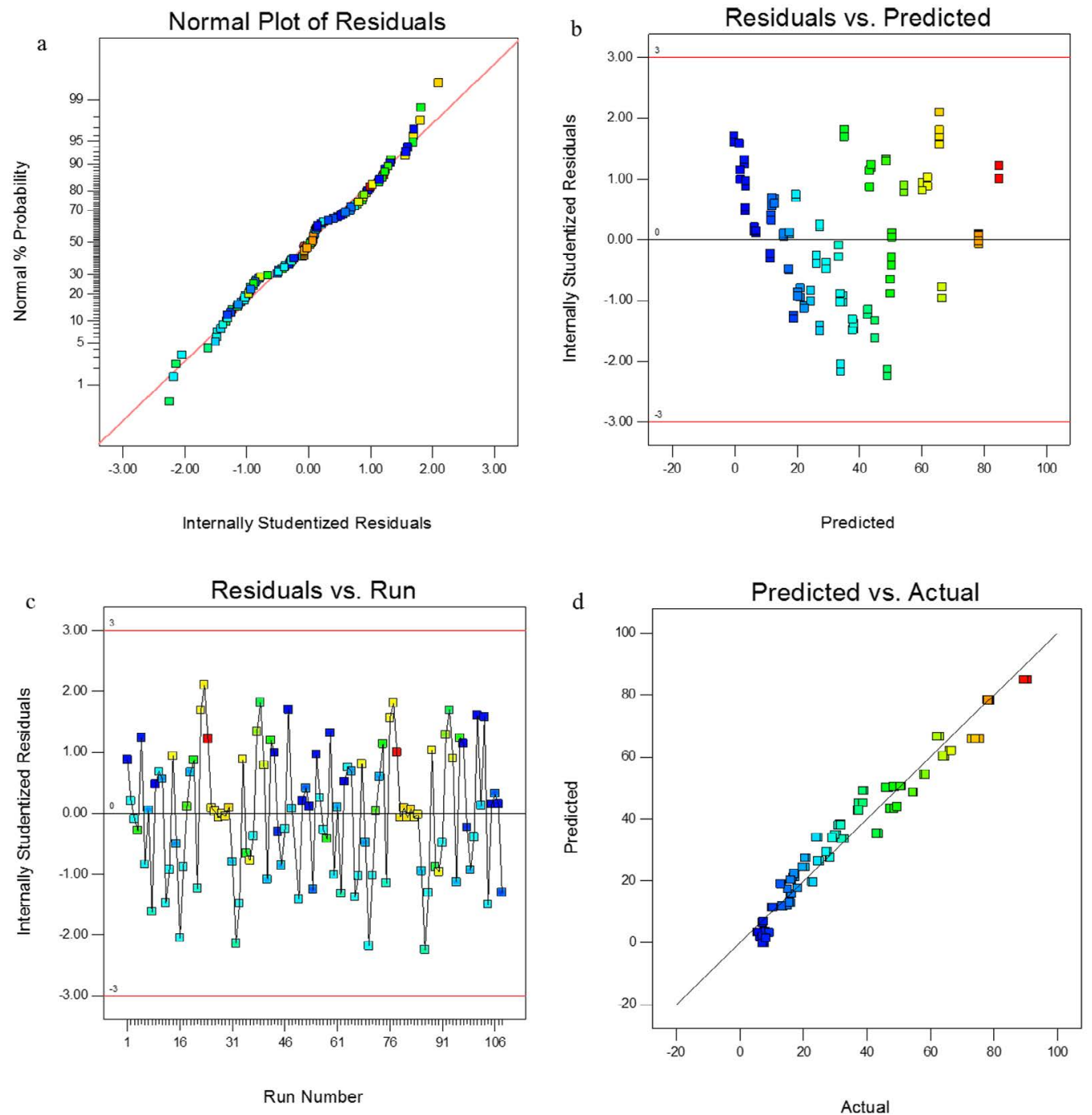

Figure 1. Distributive plotting of experimental data against the predicted valuesfor CEX removal.

Main Effects Plot for R

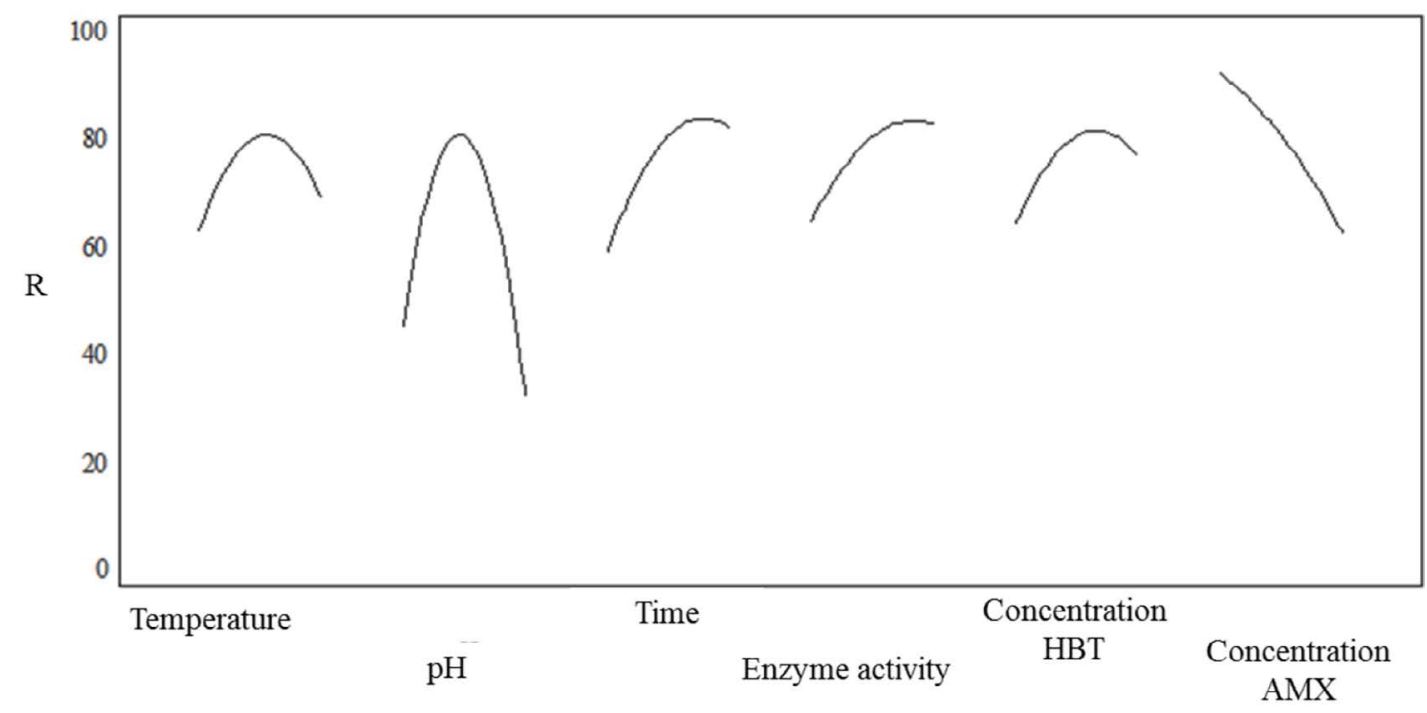

Figure 2. Chart of the Effect of Initial Factors. 


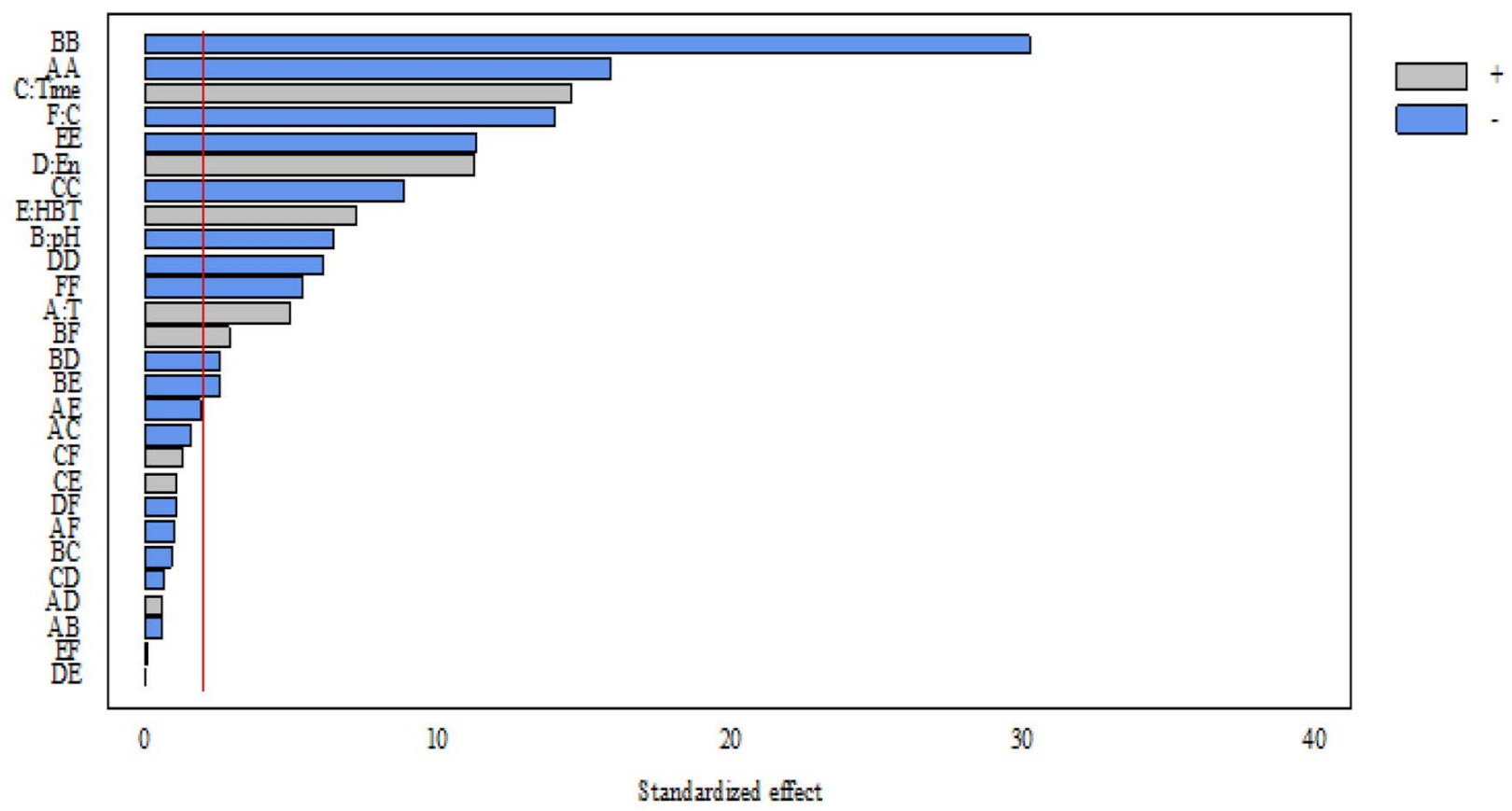

Figure 3. Pareto chart. $\mathrm{A}$ is the reaction temperature, $(\mathrm{B})$ is the $\mathrm{pH}, \mathrm{C}$ is the reaction duration, $\mathrm{D}$ is the enzyme activity, $\mathrm{E}$ is the HBT mediator concentration and $\mathrm{F}$ is the cefalexin concentration.

The effect of temperature changes on the efficacy of laccase enzyme in CEX oxidation was performed at 30,45 and $60^{\circ} \mathrm{C}$. The results are shown in Figs. 2 and 4 (a). In this process, the efficacy of CEX removal increased from 30 to $45^{\circ} \mathrm{C}$ and the highest efficiency was observed at $45^{\circ} \mathrm{C}$. As the temperature rises from $45^{\circ} \mathrm{C}$ to $60^{\circ} \mathrm{C}$, the removal efficiency decreases. Fig. 4 (a) shows the interaction between temperature and $\mathrm{pH}$, with the highest removal efficiency at 45 and $\mathrm{pH} 5$. In the studies of Forootanfar and Kim, which were performed, respectively, on wastewater and removal of bisphenol A using leccase, the best efficiency was obtained at $45{ }^{\circ} \mathrm{C}$ (Forootanfar et al., 2016; Kim and Nicell, 2006), which is consistent with the results of this research. Fig.4 (b) shows the interaction of temperature and time in enzymatic oxidation. As is evident from the figure, the efficacy of CEX removal increased upon increasing the reaction time from 15 to 60 minutes.

\section{The effect of soluble pH}

The $\mathrm{pH}$ is an important variable in enzymatic oxidation and has a great effect on the activity of the enzyme and the value of HBT radical produced (Asadgol et al., 2014; Forootanfar et al., 2016). In this study, according to Fig. 2 and 4 (a), the optimum
$\mathrm{pH}$ value is 5 and, by decreasing and increasing the $\mathrm{pH}$ away from this amount, CEX concentration is increased and, as a result, the amount of oxidation decreases. Enzymes change in nature in an acid or alkaline environment. The role of $\mathrm{pH}$ in the catalytic activity of the enzyme is due to the effect on the reactive groups of copper atoms in the laccase enzyme. The optimum $\mathrm{pH}$ for the activity of most of the fungal Laccase for oxidation is in the range of 4-6 (Baldrian, 2006). In the study of Tahmasbi et al. (2016), the enzymatic degradation of imipramine was observed at $\mathrm{pH} 3$ to 6 and an optimum $\mathrm{pH}$ of 4.9. In addition, in the study of Asadgol et al. (2014), in the elimination of bisphenol A, an optimum $\mathrm{pH}$ of 5 was obtained for laccase enzyme. These studies confirm the results of this study. In addition, Fig. 4 (a) shows the mutual effect of $\mathrm{pH}$ and temperature on CEX removal, with the highest efficiency at $\mathrm{pH} 5$ and temperature of $45^{\circ} \mathrm{C}$.

\section{The effect of enzyme activity}

The effect of laccase enzyme activity on CEX removal was evaluated at 1 and 0.25 and $1.75 \mathrm{U} / \mathrm{mL}$. The CEX oxidation pattern with increasing enzyme activity is observed in Fig. 2 and 4 (c). In this study, CEX removal is increased by increasing enzyme activity. 

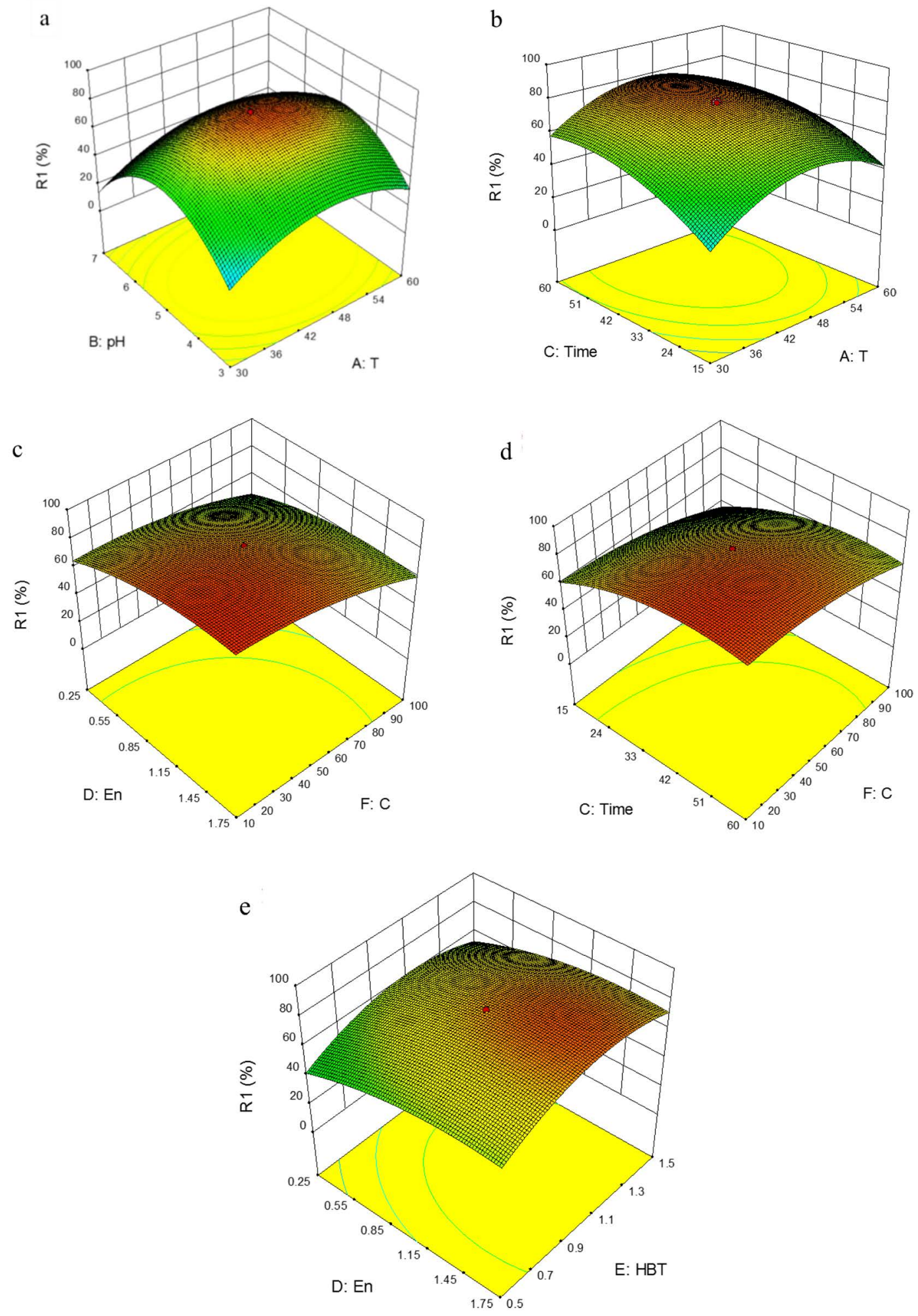

Figure 4. Responses surfaces forthe interactions of independent variables on the efficacy of CEX removal: (a) temperature and $\mathrm{pH}$; (b) temperature and reaction time; (c) enzyme activity and initial concentration of cefalexin; (d) initial concentration of CEX and time; and (e) enzyme activity and HBT concentration) 
The highest efficiency of enzyme activity is $1.75 \mathrm{U} /$ $\mathrm{mL}$. Rezaei et al. (2015) showed that with increasing activity of laccase enzyme from $0.75 \mathrm{U} / \mathrm{mL}$ to $2.5 \mathrm{U} /$ $\mathrm{mL}$, Acid Blue 92 removal efficiency increased. In the study of Forootanfar et al. (2016), it was observed that an increase in enzyme activity up to $2 \mathrm{U} / \mathrm{mL}$ increased the removal rate of stain, but an increase in enzyme activity did not have much effect on stain removal. In addition, in the study by Liu et al. (2012), it was found that increased enzyme activity increases the amount of phenol removal. This is consistent with the present study.

\section{The Effect of HBT Mediator}

This study used N-hydroxybenothiazole (HBT) as a mediator for cephalexin enzymatic oxidation at concentrations of $0.5,1$, and $1.5 \mathrm{mM}$. The interfacing activity of HBT is in enzymatic oxidation is proportional to the effect of the $\mathrm{N}-\mathrm{O}^{*}$ group on laccase activity, especially at high concentrations (Ashrafi et al., 2013; Cañas and Camarero, 2010; Papinutti et al., 2008). HBT has a high redox potential $(1084 \mathrm{mV})$ (Ostadhadi-Dehkordi et al., 2012) and the laccaseHBT system is one of the most successful laccasemediator systems for use in the removal of artificial contaminants and stains (Khlifi et al., 2010).

The results showed that the enzymatic oxidation efficiency in the presence of HBT had an increasing trend up to $1 \mathrm{mM}$ concentration, but the efficiency decreased with further increase in the concentration of HBT. The results of the effect of HBT concentrations are presented in Figs. 2 and 4 (e). The interaction between the activity of the enzyme and HBT in cefalexin oxidation is shown in Fig. 4 (e). The removal is the most at the enzyme activity of $1.75 \mathrm{U} / \mathrm{mL}$ and 1 $\mathrm{mM}$ concentration of HBT. In a study, Mirzadeh et al. (2014) used laccase enzyme to remove Acid Blue 25 and Acid Orange 7. The results of this study showed that an increase of HBT concentration up to $1 \mathrm{mM}$ increased the enzyme efficiency, but further increase in HBT had no effect on the oxidation efficiency. In addition, Khlifi et al. (2010) obtained an optimal concentration of HBT of $1 \mathrm{mM}$ in enzymatic treatment of tissue sewage, which confirms the results of this study.

\section{The Effect of Cephalexin Concentration}

The concentration of the substrate in the liquid phase has a great influence on the enzyme-mediator reaction. By increasing the concentration of the substrate proportional to the enzyme activity and the concentration of the mediator, the reaction rate increases to a certain extent, but after reaching the balance, the increase of the substrate does not affect the reaction rate. Moreover, the higher the ratio of the enzyme to the substrate, the higher the oxidation is. The study was performed at 10,80 and $100 \mathrm{mg} / \mathrm{L}$ concentrations of cefalexin, the results of which are shown in Figs. 2, 4 (d, c). Fig. 4 (c) and 4 (d), respectively, show the interaction of enzyme activity with cefalexin concentration and reaction time with concentration. By increasing the concentration of cefalexin as a substrate against the enzyme activity, the enzymatic oxidation rate constant decreases. The highest and lowest efficacy was observed in 10 and $100 \mathrm{mg} / \mathrm{L}$ concentration of cefalexin. In the removal of 2,4-dinitrophenol using laccase enzyme from the aquatic environment, Dehghanifard et al. (2013) showed that, with increasing concentrations of pollutant from 0.05 to $0.15 \mathrm{mM}$, the removal efficiency reduced, which confirms the results of this research.

\section{Process optimization}

In this study, the optimization of enzymatic oxidation was performed for the independent variables of temperature, $\mathrm{pH}$, residence time, enzyme activity, HBT mediator concentration and antibiotic concentration. The aim of this study was to determine the optimal amount of reaction time, temperature, $\mathrm{pH}$, enzyme activity, HBT mediator concentration and antibiotic initial concentration in order to achieve maximum efficacy of cefalexin removal. Different modes were tested based on the experiments using the BBD method to determine optimal conditions. Finally, the optimum conditions were determined according to Table 5. In optimal conditions, the efficacy of CEX removal was predicted to be $91 \%$. Experimental tests in similar optimized conditions with $88.8 \%$ removal efficiency confirmed this issue.

Table 5. Optimal Conditions of the Independent Variables for Cefalexin Removal

\begin{tabular}{lccc}
\hline Factor & Low & High & Optimum \\
\hline $\mathbf{T}$ & 30 & 60 & 46.6 \\
\hline $\mathbf{p H}$ & 3 & 7 & 4.6 \\
\hline Time & 15 & 60 & 48 \\
\hline $\mathbf{E n}$ & 0.25 & 1.75 & 1.54 \\
\hline HBT & 0.5 & 1.5 & 1.1 \\
\hline $\mathbf{C}$ & 10 & 100 & 11.8 \\
\hline Optimum value & & & \\
\hline
\end{tabular}




\section{CONCLUSION}

The results showed that the $\mathrm{pH}$ parameter had the most effect on CEX enzymatic oxidation with an optimum value of 5. By increasing and decreasing $\mathrm{pH}$ away from this value, oxidation and cefalexin removal reduced. The optimal enzyme oxidation conditions for CEX removal for $\mathrm{pH}$, temperature, enzyme activity, HBT concentration and CEX concentration were determined as $5,45^{\circ} \mathrm{C}, 1.75 \mathrm{U} / \mathrm{mL}, 1 \mathrm{mM}$, and $10 \mathrm{mg} / \mathrm{L}$, respectively. In these conditions, the efficiency of Laccase enzyme after 90 minutes of reaction was $90.5 \%$. Considering the results and paying attention to the acceptable performance and the appropriate removal of cefalexin by the enzyme Laccase, enzyme oxidation can be used as a suitable and high-performance process for the treatment of industrial and septic sewage containing CEX antibiotic. The findings also showed that the design of the experiment could be used to reduce costs and the number of experiments and to examine the interactions of variables and determine the optimal conditions. The cephalexin concentration range of $10-60 \mathrm{mg} / \mathrm{l}$ or less can be found in the environment (wastewater effluent of clinical centers). According to research findings, with decreasing cephalexin concentration, the removal efficiency increases. Low concentrations of cephalexin in the environment can facilitate removing this antibiotic.

\section{ACKNOWLEDGEMENTS}

This study has been adapted from a $\mathrm{PhD}$ thesis at Hamadan University of Medical Sciences. The study was funded by the Vice-Chancellor for Research and Technology, Hamadan University of Medical Sciences (No. 9412046682).

\section{REFERENCES}

Ahmed, M.J., and Theydan, S.K. Adsorption of cephalexin onto activated carbons from Albizia lebbeck seed pods by microwave-induced $\mathrm{KOH}$ and $\mathrm{K}_{2} \mathrm{CO}_{3}$ activations. Chemical Engineering Journal, 211, 200-207 (2012).

Asadgol, Z., Forootanfar, H., Rezaei, S., Mahvi, A.H., and Faramarzi, M.A. Removal of phenol and bisphenol-A catalyzed by laccase in aqueous solution. Journal of Environmental Health Science and Engineering, 12(1), 93 (2014).

Asgher, M., Noreen, S., and Bilal, M. Enhancing catalytic functionality of Trametes versicolor IBL-04 laccase by immobilization on chitosan microspheres. Chemical Engineering Research and Design, 119, 1-11 (2017).
Ashrafi, S.D., Rezaei, S., Forootanfar, H., Mahvi,A.H., and Faramarzi, M.A. The enzymatic decolorization and detoxification of synthetic dyes by the laccase from a soil-isolated ascomycete, Paraconiothyrium variabile. International Biodeterioration \& Biodegradation, 85, 173-181 (2013).

Azizi, E., Fazlzadeh, M., Ghayebzadeh, M., Hemati, L., Beikmohammadi, M., Ghaffari, H.R., Zakeri, H.R., and Sharafi, K. Application of advanced oxidation process $\left(\mathrm{H}_{2} \mathrm{O}_{2} / \mathrm{UV}\right)$ for removal of organic materials from pharmaceutical industry effluent. Environment Protection Engineering, 43, 183-191 (2017).

Baldrian, P. Fungal laccases-occurrence and properties. FEMS microbiology reviews, 30(2), 215-242 (2006).

Baquero, F., Martínez, J.-L., and Cantón, R. Antibiotics and antibiotic resistance in water environments. Current Opinion in Biotechnology, 19(3), 260-265 (2008).

Barber, M.S., Giesecke, U., Reichert, A., and Minas, W. Industrial enzymatic production of cephalosporinbased b-lactams. Advances in Biochemical Engineering Biotechnology, 88, 179-216 (2004).

Cañas, A.I., and Camarero, S. Laccases and their natural mediators: biotechnological tools for sustainable eco-friendly processes. Biotechnology Advances, 28(6), 694-705 (2010).

Chee-Sanford, J.C., Aminov, R.I., Krapac, I., Garrigues-Jeanjean, N., and Mackie, R.I. Occurrence and diversity of tetracycline resistance genes in lagoons and groundwater underlying two swine production facilities. Applied and Environmental Microbiology, 67(4), 1494-1502 (2001).

Dehghanifard, E., Jafari, A.J., Kalantary, R.R., Mahvi, A.H., Faramarzi, M.A., and Esrafili, A. Biodegradation of 2, 4-dinitrophenol with laccase immobilized on nano-porous silica beads. Iranian Journal of Environmental Health Science and Engineering, 10(1), 25 (2013).

Donati, E., Polcaro, C.M., Ciccioli, P., and Galli, E. The comparative study of a laccase-natural clinoptilolite-based catalyst activity and free laccase activity on model compounds. Journal of Hazardous Materials, 289, 83-90 (2015).

Duran, N., and Esposito, E. Potential applications of oxidative enzymes and phenoloxidase-like compounds in wastewater and soil treatment: a review. Applied Catalysis B: Environmental, 28(2), 83-99 (2000). 
Elmolla, E.S., and Chaudhuri, M. Comparison of different advanced oxidation processes for treatment of antibiotic aqueous solution. Desalination, 256(1), 43-47 (2010).

Estrada, A.L., Li, Y.-Y., and Wang, A. Biodegradability enhancement of wastewater containing cefalexin by means of the electro-Fenton oxidation process. Journal of Hazardous Materials, 227, 41-48 (2012).

Fabbrini, M., Galli, C., and Gentili, P. Radical or electron-transfer mechanism of oxidation with some laccase/mediator systems. Journal of Molecular Catalysis B: Enzymatic, 18(1), 169-171 (2002).

Fazlzadeh, M.,Ahmadfazeli,A., Entezari,A., Shaegi,A., and Khosravi, R. Removal of cephalexin using green montmorillonite loaded with $\mathrm{TiO} 2$ nanoparticles in the presence potassium permanganate from aqueous solution. Koomesh, 18, 388-396 (2016).

Fazlzadeh, M., Rahmani, A., Nasehinia, H.R., Rahmani, H., and Rahmani, K. Degradation of sulfathiazole antibiotics in aqueous solutions by using zero valent iron nanoparticles and hydrogen peroxide. Koomesh, 18, 350-356 (2016).

Forootanfar, H., Movahednia, M.M., Yaghmaei, S., Tabatabaei-Sameni, M., Rastegar, H., Sadighi, A., and Faramarzi, M.A., Removal of chlorophenolic derivatives by soil isolated ascomycete of Paraconiothyrium variabile and studying the role of its extracellular laccase. Journal of Hazardous Materials, 209, 199-203 (2012).

Forootanfar, H., Rezaei, S., Zeinvand-Lorestani, H., Tahmasbi, H., Mogharabi, M., Ameri, A., and Faramarzi, M.A., Studies on the laccase-mediated decolorization, kinetic, and microtoxicity of some synthetic azo dyes. Journal of Environmental Health Science and Engineering, 14(1), 7 (2016).

Fuoco, D. Classification framework and chemical biology of tetracycline-structure-based drugs. Antibiotics, 1(1), 1 (2012).

Guo, W., Wang, H., Shi, Y., and Zhang, G. Sonochemical degradation of the antibiotic cephalexin in aqueous solution. Water Sa, 36(5), 651-654 (2010).

Hai, F.I., Nghiem, L.D., and Modin, O. Biocatalytic membrane reactors for the removal of recalcitrant and emerging pollutants from wastewater. In Handbook of Membrane Reactors:Reactor Types andIndustrial Application, p. $763-807$ (2013).

Hata, T., Shintate, H., Kawai, S., Okamura, H., and Nishida, T. Elimination of carbamazepine by repeated treatment with laccase in the presence of 1-hydroxybenzotriazole. Journal of Hazardous Materials, 181(1), 1175-1178 (2010).
Heidary, M., Khoobi, M., Ghasemi, S., Habibi, Z., and Faramarzi, M.A. Synthesis of Quinazolinones from Alcohols via Laccase-Mediated Tandem Oxidation. Advanced Synthesis \& Catalysis, 356(8), 17891794 (2014).

Jung, S. Establishment of control system of antibiotics for livestocks. The Annual Report of KFDA, Korea, 7, 1113-1114 (2003).

Karam, J., and Nicell, J.A. Potential applications of enzymes in waste treatment. Journal of Chemical Technology \& Biotechnology, 69(2), 141-153 (1997).

Khetan, S.K., and Collins, T.J. Human pharmaceuticals in the aquatic environment: a challenge to green chemistry. Chemical Reviews, 107(6), 2319-2364 (2007).

Khlifi, R., Belbahri, L., Woodward, S., Ellouz, M., Dhouib, A., Sayadi, S., et al. Decolourization and detoxification of textile industry wastewater by the laccase-mediator system. Journal of Hazardous Materials, 175(1), 802-808 (2010).

Kim, S., Eichhorn, P., Jensen, J.N., Weber, A.S., and Aga, D.S. Removal of antibiotics in wastewater: effect of hydraulic and solid retention times on the fate of tetracycline in the activated sludge process. Environmental Science \& Technology, 39(15), 5816-5823 (2005).

Kim, Y.-J., and Nicell, J.A. Impact of reaction conditions on the laccase-catalyzed conversion of bisphenol A. Bioresource Technology, 97(12), 1431-1442 (2006).

Košutić, K.,Dolar, D., Ašperger, D., andKunst, B. Removal of antibiotics from a model wastewater by RO/NF membranes. Separation and Purification Technology, 53(3), 244-249 (2007).

Le-Minh, N., Khan, S., Drewes, J., and Stuetz, R. Fate of antibiotics during municipal water recycling treatment processes. Water Research, 44(15), 42954323 (2010).

Leili, M., Fazlzadeh, M., and Bhatnagar, A. Green synthesis of nano-zero-valent iron from Nettle and Thyme leaf extracts and their application for the removal of cephalexin antibiotic from aqueous solutions. Environmental Technology (United Kingdom), 39, 1158-1172 (2018).

Liu, Y. Laccase-catalyzed oxidation of bisphenol a in a non-aqueous liquid using reverse micelles (2006).

Liu, Z.-F., Zeng, G.-M., Zhong, H., Yuan, X.-Z., Fu, H.-Y., Zhou, M.-F., et al. Effect of dirhamnolipid on the removal of phenol catalyzed by laccase in aqueous solution. World Journal of Microbiology and Biotechnology, 28(1), 175-181 (2012). 
Lloret, L., Eibes, G., Moreira, M., Feijoo, G., and Lema, $\mathrm{J}$. On the use of a high-redox potential laccase as an alternative for the transformation of non-steroidal antiinflammatory drugs (NSAIDs). Journal of Molecular Catalysis B: Enzymatic, 97, 233-242 (2013).

Madhavi, V., and Lele, S. (2009). Laccase: properties and applications. BioResources, 4(4), 1694-1717.

Martinez, J.L. Environmental pollution by antibiotics and by antibiotic resistance determinants. Environmental pollution, 157(11), 2893-2902 (2009).

Mirzadeh, S.-S., Khezri, S.-M., Rezaei, S., Forootanfar, H., Mahvi, A.H., and Faramarzi, M.A. Decolorization of two synthetic dyes using the purified laccase of Paraconiothyrium variabile immobilized on porous silica beads. Journal of Environmental Health Science and Engineering, 12(1), 6 (2014).

Mourabet, M., El Rhilassi, A., El Boujaady, H., BennaniZiatni, M., El Hamri, R., and Taitai, A. Removal of fluoride from aqueous solution by adsorption on Apatitic tricalcium phosphate using Box-Behnken design and desirability function. Applied Surface Science, 258(10), 4402-4410 (2012).

Nazari, G., Abolghasemi, H., Esmaieli, M., and Pouya, E.S. Aqueous phase adsorption of cephalexin by walnut shell-based activated carbon: A fixed-bed column study. Applied Surface Science, 375, 144-153 (2016).

Ostadhadi-Dehkordi, S., Tabatabaei-Sameni, M., Forootanfar, H., Kolahdouz, S., Ghazi-Khansari, M., and Faramarzi, M.A. Degradation of some benzodiazepines by a laccase-mediated system in aqueous solution. Bioresource Technology, 125, 344-347 (2012).

Papinutti, L., Dimitriu, P., and Forchiassin, F. Stabilization studies of Fomes sclerodermeus laccases. Bioresource Technology, 99(2), 419-424 (2008).

Rezaei, S., Tahmasbi, H., Mogharabi, M., Ameri, A., Forootanfar, H., Khoshayand, M.R., and Faramarzi, M.A., Laccase-catalyzed decolorization and detoxification of Acid Blue 92: statistical optimization, microtoxicity, kinetics, and energetics. Journal of Environmental Health Science and Engineering, 13(1), 31(2015).
Sirés, I., and Brillas, E. Remediation of water pollution caused by pharmaceutical residues based on electrochemical separation and degradation technologies: a review. Environment International, 40, 212-229 (2012).

Tahmasbi, H., Khoshayand, M.R., BozorgiKoushalshahi, M., Heidary, M., Ghazi-Khansari, M., and Faramarzi, M.A. Biocatalytic conversion and detoxification of imipramine by the laccasemediated system. International Biodeterioration \& Biodegradation, 108, 1-8 (2016).

Vilt, M.E., and Ho, W.W. Supported liquid membranes with strip dispersion for the recovery of Cephalexin. Journal of Membrane Science, 342(1), 80-87 (2009).

Vilt, M.E., and Ho, W.W. In situ removal of Cephalexin by supported liquid membrane with strip dispersion. Journal of Membrane Science, 367(1), 71-77 (2011).

Watkinson, A., Murby, E., and Costanzo, S. Removal of antibiotics in conventional and advanced wastewater treatment: implications for environmental discharge and wastewater recycling. Water Research, 41(18), 4164-4176 (2007).

Widsten, P., and Kandelbauer, A. Laccase applications in the forest products industry: a review. Enzyme and Microbial Technology, 42(4), 293-307 (2008).

Xu, R., Tang, R., Zhou, Q., Li, F., and Zhang, B. Enhancement of catalytic activity of immobilized laccase for diclofenac biodegradation by carbon nanotubes. Chemical Engineering Journal, 262, 88-95 (2015).

Young, S., Juhl, A., and O'Mullan, G.D. Antibioticresistant bacteria in the Hudson River Estuary linked to wet weather sewage contamination. Journal of Water and Health, 11(2), 297-310 (2013).

Zazouli, M., Ulbricht, M., Nasseri, S., and Susanto, H. Effect of hydrophilic and hydrophobic organic matter on amoxicillin and cephalexin residuals rejection from water by nanofiltration. Iranian Journal of Environmental Health Science \& Engineering, 7(1), 15 (2010). 
